\title{
Study on biomethane production and biodegradability of different leafy vegetables in anaerobic digestion
}

\author{
Hu Yan ${ }^{1}$, Chen Zhao ${ }^{1}$, Jiafu Zhang ${ }^{1}$, Ruihong Zhang ${ }^{1,3}$, Chunyu Xue ${ }^{1}$, Guangqing Liu ${ }^{1 *}$ and Chang Chen ${ }^{1,2^{*}}$
}

\begin{abstract}
Enormous amounts of vegetable residues are wasted annually, causing many environmental problems due to their high moisture and organic contents. In this study, the methane production potential of 20 kinds of typical leafy vegetable residues in China were explored using a unified method. A connection between the biochemical components and the methane yields of these vegetables was well established which could be used to predict biogas performance in practice. A high volatile solid/total solid (VS/TS) ratio and hemicellulose content exhibited a positive impact on the biogas yield while lignin had a negative impact. In addition, three kinetic models were used to describe the methane production process of these agro-wastes. The systematic comparison of the methane production potentials of these leafy vegetables shown in this study will not only serve as a reference for basic research on anaerobic digestion but also provide useful data and information for agro-industrial applications of vegetable residues in future work.
\end{abstract}

Keywords: Leafy vegetable, Composition, Anaerobic digestion, Correlation, Kinetic analysis

\section{Introduction}

In China, approximately seven hundred million tons of vegetables are produced annually, with two hundred million tons of residues and wastes. The accumulation of these residues may not only cause serious environmental problems but also lead to a significant waste of resources, as the high organic content of vegetable residues could make them a potential feedstock for renewable energy. Leafy vegetable wastes are a very important class of vegetable residues. They are produced in very large amounts in all the wholesale markets in the world and their landfill disposal is quite difficult because of their perishability ( $\mathrm{Di}$ Maria et al. 2014; Scano et al. 2014). Therefore, an efficient solution to these issues is urgently needed.

Anaerobic digestion (AD) is an effective biochemical degradation method that is widely used for the treatment and energy recovery from many kinds of

\footnotetext{
*Correspondence: gqliu@mail.buct.edu.cn; chenchang@mail.buct.edu.cn 1 Biomass Energy and Environmental Engineering Research Center, College of Chemical Engineering, Beijing University of Chemical Technology, 505 Zonghe Building, 15 North 3rd Ring East Road, Beijing 100029, China

Full list of author information is available at the end of the article
}

biomasses, especially agricultural products and agrowastes. This approach has been proven to be a more outstanding method for disposing organic waste than other technology. Incineration of biomass and waste is still not fully accepted by the public opinion. And as alternative technologies, pyrolysis or gasification still does not represent a proven technology because only a limited number of full scale installations has been built (Appels et al. 2011). Compared with other techniques, AD has many economical, efficient, and environmentally friendly advantages, which make this technology applicable to industrial energy generation processes (Molino et al. 2013).

Thus far, many studies have been conducted on the $\mathrm{AD}$ of vegetables. Among the relevant studies, most have focused on comparing co-digestion using several vegetables and other feedstock (Molinuevo-Salces et al. 2010; Yao et al. 2014). Others have aimed at exploring the AD of mixed vegetables (Zhu et al. 2014). Only a few studies have compared the methanogenic potential of several types of vegetables, but there is no standard and universally recognized procedure for the determination of the biomethane yield in these researches. It is difficult to find 
any regularity because the methods were not consistent, so that the methane production potential of single leafy vegetables must be known in a uniform digestion condition. It is also necessary to establish relationships between components and methane yield, which can be used to predict biogas production performance in practice.

The purpose of this research is as follows: (1) to investigate the characteristics of 20 different types of leafy vegetable residues comprehensively, (2) to explore the methane production potential of 20 types of leafy vegetable residues in $\mathrm{AD}$ using a standard and unified digestion method, (3) to establish a connection between biochemical components and biogas production performance, and (4) to find a suitable kinetic model for describing the AD process of leafy vegetables.

\section{Materials and methods}

\section{Feedstock}

The twenty types of leafy vegetables in this study are commonly available in China, but some of them have not been previously evaluated for methane production. The Latin name, common name, and abbreviation of the feedstock are shown in Table 1. All of the vegetable residues were obtained from a vegetable market (Beijing, China) and were ground to a particle size of 2-4 mm using a grinder (JOYOUNG, China). The inoculum was anaerobic sludge collected from Beijing Donghuashan
Biogas Station which only used pig manure as a substrate. The sludge was taken each 3 months and preserved at room temperature. The total solid (TS) and volatile solid (VS) of the sludge were measured to be 6.12 and $4.14 \%$, respectively. The precipitate was used as the inoculum and added to the digester according to the $\mathrm{F} / \mathrm{I}$ ratio, and the supernate of the sludge was removed before batch digestion. The TS and VS concentrations were measured using a standard method (Clesceri et al. 2012). The elemental compositions $(\mathrm{C}, \mathrm{H}, \mathrm{N})$ were analyzed using an organic element analyzer (Vario EL cube, Germany). Oxygen contents were determined (Rincon et al. 2012) by assuming $\mathrm{C}+\mathrm{H}+\mathrm{O}+\mathrm{N}=99.5 \%$ (on a VS basis). The contents of cellulose, hemicellulose, and lignin were determined using an AMKOM 2000 fiber analyzer (AMKOM, USA) by measuring neutral detergent fiber (NDF), acid detergent fiber (ADF), and acid detergent lignin (ADL) (Van Soest et al. 1991). Soluble protein and non-structural carbohydrate contents were measured by the Bradford method (Barbosa et al. 2009; Silvério et al. 2012) and the DNS assay (Marsden et al. 2007; Miller 1959), respectively. Lipid contents were determined by Soxhlet extraction using diethyl ether as the solvent (Xu and $\mathrm{Li} \mathrm{2012).} \mathrm{The} \mathrm{volatile} \mathrm{fatty} \mathrm{acids}$ (VFAs) contents were measured by an Agilent 7890A gas chromatograph equipped with a flame ionization detector with nitrogen as the carrier gas, using a previously reported method (Li et al. 2013a).

Table 1 Latin name, common name, and abbreviation of feedstock

\begin{tabular}{|c|c|c|}
\hline Latin name & Common name & Abbreviation in this study \\
\hline Brassica oleracea L. var. capitata L. & Cabbage & V1 \\
\hline Brassica pekinensis (Lour.) Rupr. & Chinese cabbage & V2 \\
\hline Mentha haplocalyx Briq. & Mint & V3 \\
\hline Allium sativum $L$. & Young garlic shoot & V4 \\
\hline Toona sinensis (Juss.) M. Roem. & Chinese toon sprout & V5 \\
\hline Andrographis paniculata (Burm.f.) Nees & Common andrographis & V6 \\
\hline Nepeta cataria L. & Schizonepeta & V7 \\
\hline Coriandrum sativum L. & Coriander & V8 \\
\hline Brassica oleracea L. var.italic Planch. & Broccoli & V9 \\
\hline Brassica campestris L. var. purpuraria L. H. Bailey & Purple cabbage & V10 \\
\hline Lactuca sativa L. var. ramosa Hort. & Romaine lettuce & V11 \\
\hline Spinacia oleracea L. & Spinach & V12 \\
\hline Chrysanthemum coronarium L. & Crowndaisy chrysanthemum & V13 \\
\hline Brassica oleracea L. var. botrytis L. & Cauliflower & V14 \\
\hline Oenanthe javanica (BI.) DC. & Celery & V15 \\
\hline Lactuca sativa L. & Lettuce & V16 \\
\hline Amaranthus tricolor $\mathrm{L}$. & Amaranth wood & V17 \\
\hline Ipomoea aquatica Forssk. & Water spinach & V18 \\
\hline Allium tuberosum Rottler ex Spreng. & Leek & V19 \\
\hline Scrophularia ningpoensis Hemsl. & Summer radish & V20 \\
\hline
\end{tabular}




\section{Methane production}

Briefly, different leafy vegetables were tested in reaction bottles (total volume of $500 \mathrm{~mL}$ ). The initial VS concentration for batch feeding was set to $5 \mathrm{~g} / \mathrm{L}$, and the feedstock to inoculum ratio was 1 . Distilled water was then added to a working volume of $250 \mathrm{~mL}$. All oxygen was discharged from the digesters by filling with nitrogen gas and the digesters were then sealed with a rubber plug. After that, the digesters were placed in an incubator at $37{ }^{\circ} \mathrm{C}$ for 25 days. All bottles were shaken manually for $1 \mathrm{~min}$ twice a day. Three parallel samples were used for each vegetable to ensure accuracy. Biogas yield was calculated according to our previous paper (Liu et al. 2015). Methane content was analyzed using a 7890A GC (Agilent, USA) equipped with a thermal conductivity detector, with helium as the carrier gas (Li et al. 2013c).

\section{Determination of biodegradability}

To calculate the theoretical maximum methane production (MMP), two methods were applied in this research (Buswell and Mueller 1952; Li et al. 2013b), one of which was based on the elemental content, as shown in Eqs. (1) and (2):

$$
\begin{aligned}
& \mathrm{C}_{n} \mathrm{H}_{a} \mathrm{O}_{b} \mathrm{~N}_{c}+\left(n-\frac{a}{4}-\frac{b}{2}+\frac{3 c}{4}\right) \mathrm{H}_{2} \mathrm{O} \\
& \rightarrow\left(\frac{n}{2}+\frac{a}{8}-\frac{b}{4}-\frac{3 c}{8}\right) \mathrm{CH}_{4} \\
& +\left(\frac{n}{2}-\frac{a}{8}+\frac{b}{4}+\frac{3 c}{8}\right) \mathrm{CO}_{2}+c \mathrm{NH}_{3} \\
& \operatorname{MMP}_{\text {ele }}\left(\frac{\mathrm{mLCH}_{4}}{\mathrm{gVS}}\right)=\frac{22.4 \times 1000 \times\left(\frac{n}{2}+\frac{a}{8}-\frac{b}{4}-\frac{3 c}{8}\right)}{12 n+a+16 b+14 c}
\end{aligned}
$$

The second method for calculating the MMP was based on the organic composition, as shown in Eq. (3) (Rincón et al. 2012):

$$
\begin{aligned}
\mathrm{MMP}_{\text {org }}\left(\frac{\mathrm{mLCH}_{4}}{\mathrm{gVS}}\right) \\
=\left(\begin{array}{l}
\text { 373VFA }+496 \text { Protein }+1014 \text { Lipids }+ \\
415 \text { Carbohydrates }+727 \text { Lignin }
\end{array}\right) / 100
\end{aligned}
$$

All of the compositions in Eq. (3) were calculated based on VS, including volatile fatty acids $\left(\right.$ as $\left.\mathrm{C}_{2} \mathrm{H}_{4} \mathrm{O}_{2}\right)$, proteins (as $\mathrm{C}_{5} \mathrm{H}_{7} \mathrm{NO}_{2}$ ), carbohydrates $\left(\right.$ as $\mathrm{C}_{6} \mathrm{H}_{10} \mathrm{O}_{5}$ ), and lignins (as $\mathrm{C}_{10} \mathrm{H}_{13} \mathrm{O}_{3}$ ). The biodegradability (BD) can be obtained from the highest cumulative methane yield from experiment (experimental methane yield, EMY) and the MMP through two methods, as described in Eqs. (4) and (5):

$$
\begin{aligned}
& \mathrm{BD}_{\text {ele }}=\mathrm{EMY} / \mathrm{MMP}_{\text {ele }} \\
& \mathrm{BD}_{\text {org }}=\mathrm{EMY} / \mathrm{MMP}_{\text {org }}
\end{aligned}
$$

\section{Kinetic modeling}

Various kinetic models have been widely used to describe the process of $\mathrm{AD}$. In this study, three of them were chosen. The first model is the first-order kinetic model, expressed as Eq. (6) (Lo et al. 2010):

$$
B=B_{0}[1-\exp (-k t)]
$$

As shown in the equation, $B$ represents the simulated cumulative methane yield ( $\left.\mathrm{mL} \mathrm{g}_{\mathrm{VS}}^{-1}\right), B_{0}$ refers to the simulated maximum cumulative methane yield $\left(\mathrm{mL} \mathrm{g}_{\mathrm{VS}}^{-1}\right)$ of the vegetable residues, and $k$ and $t$ denote the first-order rate constant $\left(\mathrm{d}^{-1}\right)$ and digestion time (d), respectively.

Another equation, the modified Gompertz model (Syaichurrozi et al. 2013), is expressed as Eq. (7):

$$
B=B_{0} \times \exp \left\{-\exp \left[\frac{\mu \mathrm{e}}{B_{0}}(\lambda-t)+1\right]\right\}
$$

where $B$ represents the simulated cumulative methane yield $\left(\mathrm{mL} \mathrm{g}_{\mathrm{VS}}^{-1}\right), B_{0}$ means the simulated maximum cumulative methane yield $\left(\mathrm{mL} \mathrm{g} \mathrm{gS}_{\mathrm{VS}}^{-1}\right), \mu$ stands for the maximum methane production rate $\left(\mathrm{mL} \mathrm{g}_{\mathrm{VS}}^{-1} \mathrm{~d}^{-1}\right), \lambda$ refers to the lag phase time (d), $t$ represents digestion time (d), and e is equal to 2.7183 .

The last model is the MBPPSA model (Owamah and Izinyon 2015), as expressed in Eq. (8):

$$
B=B_{0}[1-\exp (-k t)]^{n}+I_{0}
$$

In this model, $B$ represents the simulated cumulative methane yield ( $\left.\mathrm{mL} \mathrm{g} \mathrm{VS}_{\mathrm{VS}}^{-1}\right), B_{0}$ refers to the simulated maximum cumulative methane yield ( $\mathrm{mL} \mathrm{g}-1$ VS $), k$ means a constant of the model $\left(\mathrm{d}^{-1}\right), t$ is digestion time $(\mathrm{d}), n$ stands for the number of data points, and $I_{0}$ represents an inhibition/stability/feasibility determination factor.

\section{Data processing}

All experiments were performed in triplicate. Microsoft Excel 2010 (Microsoft, USA) was used for data processing. Origin 8.0 (OriginLab, USA) was used for graphing and fitting.

\section{Results}

\section{Characteristics of feedstock}

The characteristics of the samples are shown in Table 2. Generally, leafy vegetables had low TS contents (2.83$11.19 \%)$, which corresponded to their high moisture contents. Mint (10.89\%), young garlic shoot $(10.50 \%)$, and coriander (11.19\%) had higher TS contents compared with those of the other samples (below 10\%). The VS/TS ratios were found to range from 69.15 to $94.76 \%$. Nine types of 
Table 2 Physicochemical analysis and elemental compositions of leafy vegetable residues

\begin{tabular}{|c|c|c|c|c|c|c|c|c|}
\hline Samples & TS (\%) & VS (\%) & VS/TS (\%) & C (\%TS) & H (\%TS) & $\mathrm{O}$ (\%TS) & $\mathrm{N}$ (\%TS) & $\mathrm{C} / \mathrm{N}$ \\
\hline V1 & $4.82 \pm 0.02$ & $4.35 \pm 0.02$ & 90.25 & $39.51 \pm 0.12$ & $5.75 \pm 0.01$ & $40.00 \pm 0.13$ & $4.54 \pm 0.01$ & 8.70 \\
\hline V2 & $3.47 \pm 0.02$ & $2.86 \pm 0.03$ & 82.42 & $35.66 \pm 0.21$ & $5.26 \pm 0.01$ & $35.73 \pm 0.05$ & $5.36 \pm 0.01$ & 6.65 \\
\hline V3 & $10.89 \pm 0.05$ & $9.45 \pm 0.05$ & 86.78 & $42.82 \pm 0.13$ & $5.81 \pm 0.01$ & $32.03 \pm 0.07$ & $5.68 \pm 0.01$ & 7.54 \\
\hline V4 & $10.50 \pm 0.06$ & $9.95 \pm 0.05$ & 94.76 & $44.58 \pm 0.23$ & $6.07 \pm 0.02$ & $39.11 \pm 0.04$ & $4.53 \pm 0.01$ & 9.84 \\
\hline V5 & $8.04 \pm 0.09$ & $7.26 \pm 0.08$ & 90.30 & $43.60 \pm 0.15$ & $6.24 \pm 0.01$ & $33.47 \pm 0.02$ & $6.54 \pm 0.01$ & 6.67 \\
\hline V6 & $4.96 \pm 0.05$ & $3.43 \pm 0.05$ & 69.15 & $35.06 \pm 0.41$ & $4.81 \pm 0.01$ & $24.60 \pm 0.07$ & $4.34 \pm 0.00$ & 8.08 \\
\hline V7 & $6.41 \pm 0.04$ & $4.83 \pm 0.00$ & 75.35 & $37.04 \pm 0.06$ & $5.23 \pm 0.01$ & $27.50 \pm 0.11$ & $5.20 \pm 0.01$ & 7.12 \\
\hline V8 & $11.19 \pm 0.19$ & $8.18 \pm 0.17$ & 73.10 & $37.88 \pm 0.17$ & $5.47 \pm 0.01$ & $24.60 \pm 0.10$ & $4.79 \pm 0.01$ & 7.91 \\
\hline V9 & $8.96 \pm 0.07$ & $8.10 \pm 0.07$ & 90.40 & $42.24 \pm 0.23$ & $6.32 \pm 0.02$ & $35.48 \pm 0.06$ & $5.91 \pm 0.00$ & 7.15 \\
\hline V10 & $6.89 \pm 0.07$ & $6.29 \pm 0.07$ & 91.29 & $41.61 \pm 0.23$ & $5.81 \pm 0.03$ & $39.88 \pm 0.05$ & $3.53 \pm 0.01$ & 11.79 \\
\hline V11 & $2.83 \pm 0.01$ & $2.47 \pm 0.01$ & 87.28 & $43.16 \pm 0.13$ & $5.58 \pm 0.01$ & $33.80 \pm 0.06$ & $4.30 \pm 0.01$ & 10.04 \\
\hline V12 & $7.22 \pm 0.22$ & $5.26 \pm 0.15$ & 72.85 & $31.04 \pm 0.08$ & $4.38 \pm 0.01$ & $33.17 \pm 0.08$ & $3.90 \pm 0.02$ & 7.96 \\
\hline V13 & $5.11 \pm 0.06$ & $3.86 \pm 0.02$ & 75.54 & $33.12 \pm 0.15$ & $4.77 \pm 0.01$ & $33.53 \pm 0.09$ & $3.74 \pm 0.01$ & 8.86 \\
\hline V14 & $5.69 \pm 0.06$ & $5.13 \pm 0.05$ & 90.16 & $41.49 \pm 0.11$ & $6.29 \pm 0.01$ & $35.83 \pm 0.04$ & $6.09 \pm 0.01$ & 6.81 \\
\hline V15 & $5.80 \pm 0.06$ & $4.28 \pm 0.06$ & 73.79 & $30.40 \pm 0.08$ & $4.60 \pm 0.01$ & $34.18 \pm 0.11$ & $4.25 \pm 0.02$ & 7.15 \\
\hline V16 & $6.94 \pm 0.10$ & $6.12 \pm 0.11$ & 88.18 & $38.97 \pm 0.16$ & $5.39 \pm 0.01$ & $38.89 \pm 0.05$ & $4.49 \pm 0.03$ & 8.68 \\
\hline V17 & $5.91 \pm 0.24$ & $4.29 \pm 0.20$ & 72.59 & $33.06 \pm 0.10$ & $4.78 \pm 0.01$ & $29.76 \pm 0.03$ & $4.62 \pm 0.01$ & 7.16 \\
\hline V18 & $5.52 \pm 0.02$ & $4.46 \pm 0.02$ & 80.80 & $36.28 \pm 0.09$ & $5.19 \pm 0.01$ & $34.35 \pm 0.04$ & $4.58 \pm 0.01$ & 7.92 \\
\hline V19 & $7.37 \pm 0.05$ & $6.17 \pm 0.04$ & 83.72 & $38.12 \pm 0.13$ & $5.62 \pm 0.01$ & $34.55 \pm 0.06$ & $5.01 \pm 0.00$ & 7.61 \\
\hline V20 & $4.13 \pm 0.03$ & $3.17 \pm 0.01$ & 76.76 & $35.55 \pm 0.07$ & $5.27 \pm 0.02$ & $30.44 \pm 0.05$ & $5.11 \pm 0.01$ & 6.96 \\
\hline
\end{tabular}

leafy vegetables showed relatively high VS/TS ratios (over $85 \%$ ), and usually a high organic content was beneficial for methane production. The $\mathrm{C} / \mathrm{N}$ ratios were generally low, in the range of $6.65-11.79$. Only purple cabbage (11.79) and romaine lettuce (10.04) had ratios higher than 10.

The biochemical compositions of the samples are shown in Table 3. The contents of soluble proteins, VFAs, lipids, and non-structural carbohydrates were relatively low. The contents of proteins and VFAs were in the ranges of $0.12-1.35 \%$ and $0.23-3.01 \%$, respectively. The lipid contents ranged from 1.02 to $5.51 \%$, and the contents of non-structural carbohydrates were in the range of $0.01-6.53 \%$. The ash contents were in the range of $5.24-30.78 \%$. Table 3 demonstrated that the main organic components of leafy vegetables were structural carbohydrates, including hemicellulose (14.37-68.24\%), cellulose (6.61-20.67\%), and lignin (0.22-12.12\%). The largest differences were reflected in the content of hemicellulose, which might influence methane production.

\section{Methane production}

The methane production performance and biodegradability (BD) of leafy vegetables are shown in Table 4 . The highest and lowest EMY values were observed from cauliflower $\left(249.61 \mathrm{~mL} \mathrm{~g} \mathrm{VS}_{\mathrm{VS}}^{-1}\right)$ and schizonepeta $(81.52 \mathrm{~mL}$ $\mathrm{g}_{\mathrm{VS}}^{-1}$ ), respectively. The MMP ${ }_{\text {org }}$ values ranged from 385.95 to $521.85 \mathrm{~mL} \mathrm{~g}_{\mathrm{VS}}^{-1}$, while the $\mathrm{MMP}_{\text {ele }}$ values were in the range of $364.13-538.65 \mathrm{~mL} \mathrm{~g}_{\mathrm{VS}}^{-1}$. Generally, the $\mathrm{MMP}_{\text {org }}$ and $\mathrm{MMP}_{\text {ele }}$ values were similar for each vegetable except coriander. The $\mathrm{BD}$ values were calculated based on the ratio of EMY to MMP. The results showed that the highest and lowest BD of the feedstocks were $60.57 \%$ (broccoli) and $18.79 \%$ (schizonepeta), respectively, based on organic composition. On an elemental basis, the highest BD was $55.77 \%$ (cauliflower) and the lowest was $16.76 \%$ (schizonepeta). In addition, feedstocks with high EMY values also showed relative high biodegradability.

\section{Correlation analysis}

Based on the biochemical compositions reported in Table 3, the appropriate functional forms of every organic component were determined based on differences in the regression coefficients $\left(R^{2}\right)$, and the results are shown in Fig. 1a-e. To explore the connection between EMY and the organic components, multiple linear regression analysis was applied. VFA and soluble protein levels were not considered as variables in the regression because their effects were proportionally small. Functional form for each organic component in the multiple linear regression model was determined through separate linear regression analysis. In addition, cellulose and lipid contents were found to have little influence in different forms, and no clear relations were observed with respect to EMY, thus, these forms were treated as simple functions.

According to the nonlinear curve fitting, a relational expression was discovered using the least squares 
Table 3 Biochemical compositions of leafy vegetable residues (based on TS)

\begin{tabular}{|c|c|c|c|c|c|c|c|c|}
\hline \multirow[t]{2}{*}{ Samples } & \multirow[t]{2}{*}{ Proteins (\%) } & \multirow{2}{*}{$\begin{array}{l}\text { VFAs } \\
\text { (\%) }\end{array}$} & \multirow{2}{*}{$\begin{array}{l}\text { Lipids } \\
\text { (\%) }\end{array}$} & \multicolumn{3}{|c|}{ Structural carbohydrates } & \multirow{2}{*}{$\begin{array}{l}\text { Non-structural } \\
\text { carbohydrates (\%) }\end{array}$} & \multirow[t]{2}{*}{ Ash (\%) } \\
\hline & & & & Hemicellulose (\%) & Cellulose (\%) & Lignin (\%) & & \\
\hline V1 & $1.04 \pm 0.01$ & $0.35 \pm 0.00$ & $2.11 \pm 0.03$ & $68.24 \pm 1.86$ & $13.52 \pm 0.61$ & $0.44 \pm 0.00$ & $0.29 \pm 0.00$ & $9.75 \pm 0.02$ \\
\hline V2 & $1.13 \pm 0.00$ & $1.04 \pm 0.00$ & $1.26 \pm 0.01$ & $60.22 \pm 4.00$ & $16.46 \pm 1.63$ & $0.22 \pm 0.13$ & $6.53 \pm 0.05$ & $17.70 \pm 0.53$ \\
\hline V3 & $0.42 \pm 0.00$ & $0.23 \pm 0.01$ & $5.51 \pm 0.03$ & $33.38 \pm 0.18$ & $16.62 \pm 0.10$ & $10.34 \pm 0.11$ & $2.42 \pm 0.01$ & $13.21 \pm 0.12$ \\
\hline V4 & $0.55 \pm 0.00$ & $0.78 \pm 0.01$ & $4.33 \pm 0.01$ & $62.28 \pm 0.56$ & $12.87 \pm 0.93$ & $3.86 \pm 0.61$ & $2.02 \pm 0.00$ & $5.24 \pm 0.01$ \\
\hline V5 & $0.56 \pm 0.00$ & $0.88 \pm 0.02$ & $5.07 \pm 0.05$ & $38.14 \pm 3.47$ & $17.27 \pm 1.13$ & $10.30 \pm 0.55$ & $0.03 \pm 0.00$ & $9.77 \pm 0.04$ \\
\hline V6 & $0.78 \pm 0.01$ & $0.76 \pm 0.00$ & $2.64 \pm 0.02$ & $50.97 \pm 0.37$ & $12.08 \pm 0.05$ & $5.76 \pm 0.73$ & $0.01 \pm 0.00$ & $30.78 \pm 0.30$ \\
\hline V7 & $0.15 \pm 0.00$ & $3.01 \pm 0.03$ & $3.52 \pm 0.01$ & $14.37 \pm 2.06$ & $19.53 \pm 1.02$ & $12.12 \pm 1.56$ & $0.02 \pm 0.00$ & $24.63 \pm 0.45$ \\
\hline V8 & $0.88 \pm 0.01$ & $0.80 \pm 0.00$ & $5.35 \pm 0.05$ & $31.95 \pm 3.18$ & $14.55 \pm 0.34$ & $5.96 \pm 0.50$ & $0.35 \pm 0.00$ & $26.88 \pm 0.27$ \\
\hline V9 & $0.71 \pm 0.00$ & $0.34 \pm 0.01$ & $2.98 \pm 0.01$ & $54.89 \pm 3.53$ & $14.43 \pm 0.77$ & $3.90 \pm 0.69$ & $0.31 \pm 0.01$ & $9.52 \pm 0.05$ \\
\hline V10 & $0.57 \pm 0.00$ & $0.30 \pm 0.00$ & $3.53 \pm 0.03$ & $61.54 \pm 3.21$ & $11.04 \pm 5.81$ & $5.26 \pm 0.25$ & $1.62 \pm 0.02$ & $8.76 \pm 0.10$ \\
\hline V11 & $1.35 \pm 0.01$ & $1.90 \pm 0.02$ & $4.79 \pm 0.03$ & $56.36 \pm 0.50$ & $14.08 \pm 1.30$ & $4.88 \pm 1.33$ & $0.16 \pm 0.00$ & $12.47 \pm 0.08$ \\
\hline V12 & $0.23 \pm 0.00$ & $0.59 \pm 0.00$ & $3.37 \pm 0.03$ & $24.85 \pm 0.28$ & $7.87 \pm 0.89$ & $9.43 \pm 1.35$ & $0.03 \pm 0.00$ & $27.19 \pm 0.08$ \\
\hline V13 & $0.12 \pm 0.00$ & $0.76 \pm 0.00$ & $2.14 \pm 0.01$ & $29.71 \pm 5.15$ & $18.95 \pm 0.46$ & $8.53 \pm 1.40$ & $0.02 \pm 0.00$ & $24.51 \pm 0.38$ \\
\hline V14 & $0.80 \pm 0.00$ & $1.01 \pm 0.04$ & $2.05 \pm 0.01$ & $47.51 \pm 4.32$ & $6.61 \pm 1.18$ & $3.87 \pm 1.26$ & $1.55 \pm 0.02$ & $9.83 \pm 0.13$ \\
\hline V15 & $0.53 \pm 0.00$ & $0.73 \pm 0.00$ & $1.51 \pm 0.03$ & $37.84 \pm 2.43$ & $19.22 \pm 0.78$ & $3.32 \pm 1.57$ & $0.07 \pm 0.00$ & $26.18 \pm 0.29$ \\
\hline V16 & $1.21 \pm 0.00$ & $0.69 \pm 0.01$ & $4.02 \pm 0.05$ & $35.45 \pm 2.91$ & $20.67 \pm 1.12$ & $6.16 \pm 0.48$ & $0.84 \pm 0.01$ & $11.83 \pm 0.22$ \\
\hline V17 & $1.28 \pm 0.00$ & $1.09 \pm 0.00$ & $1.02 \pm 0.01$ & $37.98 \pm 2.82$ & $10.50 \pm 0.73$ & $11.13 \pm 1.69$ & $0.02 \pm 0.00$ & $27.38 \pm 0.34$ \\
\hline V18 & $0.42 \pm 0.00$ & $0.48 \pm 0.01$ & $1.66 \pm 0.05$ & $41.05 \pm 0.95$ & $14.61 \pm 1.61$ & $10.42 \pm 1.77$ & $0.02 \pm 0.00$ & $19.11 \pm 0.05$ \\
\hline V19 & $0.80 \pm 0.01$ & $1.54 \pm 0.00$ & $2.71 \pm 0.03$ & $54.90 \pm 4.60$ & $13.61 \pm 0.68$ & $4.81 \pm 0.70$ & $0.36 \pm 0.00$ & $16.32 \pm 0.02$ \\
\hline V20 & $0.30 \pm 0.00$ & $1.10 \pm 0.00$ & $3.42 \pm 0.05$ & $36.91 \pm 2.97$ & $15.64 \pm 0.38$ & $4.41 \pm 0.55$ & $0.93 \pm 0.00$ & $23.17 \pm 0.69$ \\
\hline
\end{tabular}

Table 4 Methane production potential and biodegradability of the feedstock

\begin{tabular}{|c|c|c|c|c|c|c|}
\hline Samples & EMY $\mathrm{mL}_{\mathrm{vs}}^{-1}$ & $\mathrm{MMP}_{\text {org }} \mathrm{mL} \mathrm{g}_{\mathrm{vs}}^{-1}$ & $\mathrm{MMP}_{\text {ele }} \mathrm{mL} \mathrm{g}_{\mathrm{vs}}^{-1}$ & $\mathrm{BD}_{\text {org }} \%$ & $\mathrm{BD}_{\text {ele }} \%$ & $E M Y^{\prime} m L g_{v s}^{-1}$ \\
\hline V1 & 204.34 & 413.65 & 403.75 & 49.40 & 50.61 & 215.25 \\
\hline V2 & 129.34 & 449.07 & 393.73 & 28.80 & 32.85 & 131.65 \\
\hline V3 & 131.25 & 454.54 & 482.11 & 28.88 & 27.23 & 142.67 \\
\hline V4 & 227.88 & 436.75 & 447.51 & 52.17 & 50.92 & 241.38 \\
\hline V5 & 129.11 & 448.73 & 473.37 & 28.77 & 27.27 & 139.35 \\
\hline V6 & 118.04 & 521.85 & 508.20 & 22.62 & 23.23 & 198.40 \\
\hline V7 & 81.52 & 433.78 & 486.45 & 18.79 & 16.76 & 85.69 \\
\hline V8 & 199.61 & 443.31 & 538.65 & 45.03 & 37.06 & 179.76 \\
\hline V9 & 246.87 & 407.57 & 457.55 & 60.57 & 53.95 & 210.76 \\
\hline V10 & 232.70 & 446.68 & 429.78 & 52.10 & 54.14 & 240.91 \\
\hline V11 & 244.41 & 471.01 & 477.97 & 51.89 & 51.13 & 198.55 \\
\hline V12 & 157.90 & 385.95 & 376.24 & 40.91 & 41.97 & 157.55 \\
\hline V13 & 189.22 & 429.69 & 402.81 & 44.04 & 46.98 & 159.85 \\
\hline V14 & 249.61 & 463.62 & 447.55 & 53.84 & 55.77 & 237.73 \\
\hline V15 & 164.38 & 400.65 & 364.13 & 41.03 & 45.14 & 184.01 \\
\hline V16 & 199.07 & 403.74 & 400.65 & 49.31 & 49.69 & 198.89 \\
\hline V17 & 130.54 & 480.96 & 429.94 & 27.14 & 30.36 & 133.74 \\
\hline V18 & 171.50 & 458.87 & 418.14 & 37.37 & 41.01 & 148.18 \\
\hline V19 & 182.83 & 451.51 & 434.66 & 40.49 & 42.06 & 211.99 \\
\hline V20 & 183.51 & 407.17 & 447.93 & 45.07 & 40.97 & 212.60 \\
\hline
\end{tabular}



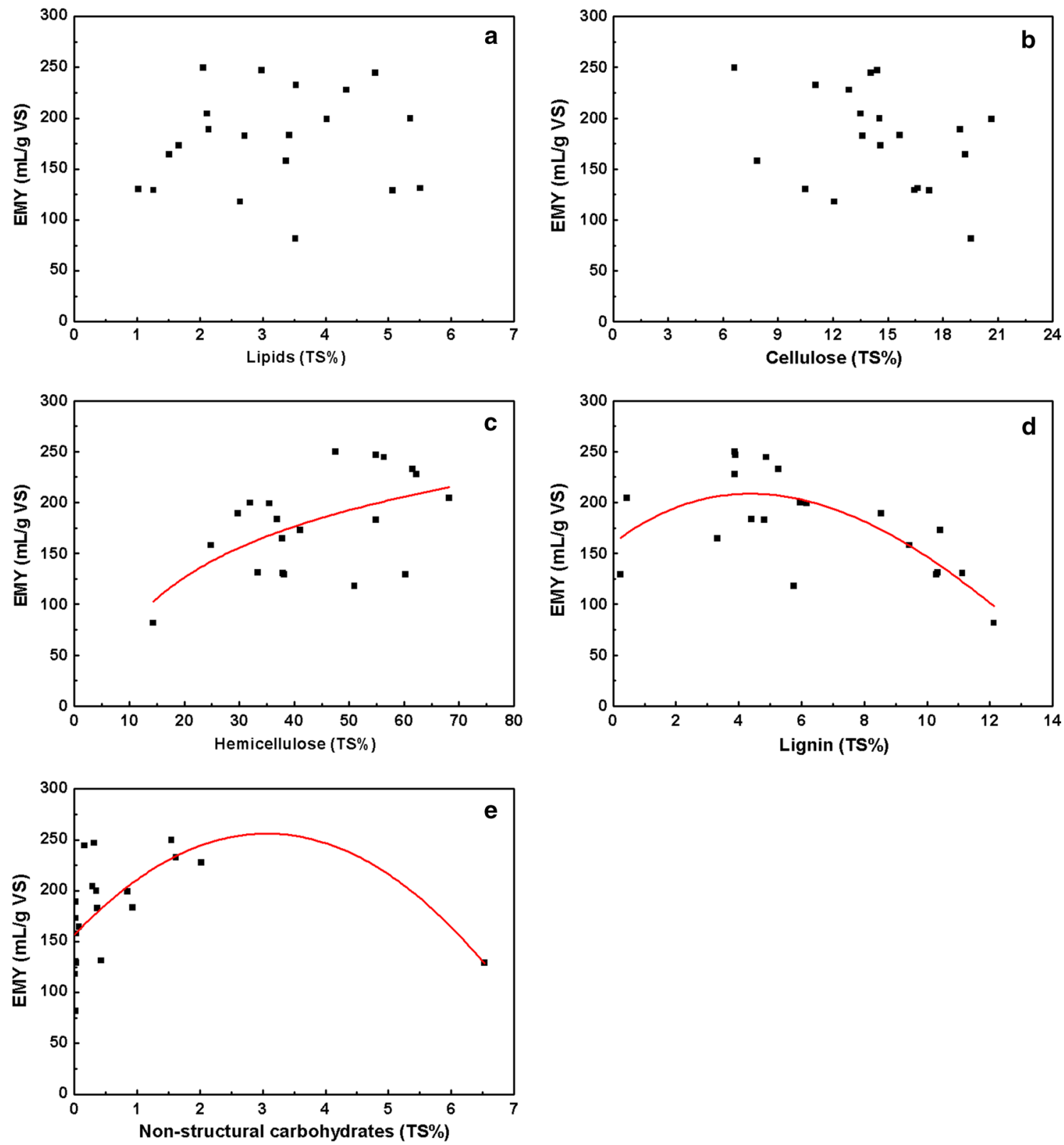

Fig. 1 Correlation between lipids, hemicellulose, cellulose, lignin, and non-structural carbohydrates contents and experimental methane yield (a-e, respectively) of 20 kinds of leafy vegetables

method with the software EVIEWS (QMS, USA), as shown in Eq. (9):

$$
\begin{aligned}
E M Y^{\prime}= & 82.33-2.28 a^{2}+13.46 a+28.17 \ln (b)-0.96 c \\
& -0.07 d^{3}+0.39 d^{2}-0.43 d-6.47 e^{2}+32.54 e
\end{aligned}
$$

In this formula, the variables are expressed as a percentage of TS. Variables a, b, c, d, and e refer to the contents of lipids, hemicellulose, cellulose, lignin, and non-structural carbohydrates, respectively. The EMY' (simulated experimental methane yield) values of the feedstocks were calculated according to the equation $\left(R^{2}=0.913\right)$ and are shown in Table 4.

\section{Kinetic evaluation}

The first-order, modified Gompertz, and MBPPSA models were used for kinetic evaluation, and the results are shown in Table 5. Four representative leafy vegetables (V3, V7, V14, V16) with different EMY values were 
Table 5 Parameters in different kinetic models

\begin{tabular}{|c|c|c|c|c|c|c|c|c|c|c|c|c|c|}
\hline \multirow[t]{2}{*}{ Samples } & \multicolumn{3}{|c|}{ First-order model } & \multicolumn{4}{|c|}{ Modified Gompertz model } & \multicolumn{5}{|c|}{ MBPPSA model } & \multirow[t]{2}{*}{ EMY $m L g_{v s}^{-1}$} \\
\hline & $B_{0} \mathrm{~mL} \mathrm{~g}_{\mathrm{vs}}^{-1}$ & $k \mathrm{~d}^{-1}$ & $\mathrm{R}^{2}$ & $B_{0} \mathrm{~mL} \mathrm{~g}_{\mathrm{vs}}^{-1}$ & $\mu \mathrm{mL} \mathrm{g}_{\mathrm{vs}}^{-1} \mathrm{~d}^{-1}$ & $\lambda d$ & $\mathrm{R}^{2}$ & $B_{0} \mathrm{~mL} \mathrm{~g}_{\mathrm{vs}}^{-1}$ & $k \mathrm{~d}^{-1}$ & $n$ & $I_{0}$ & $\mathrm{R}^{2}$ & \\
\hline V1 & 231 & 0.11 & 0.940 & 230 & 29.64 & 1.90 & 0.999 & 221 & 0.34 & 4.85 & 10.87 & 0.999 & 204 \\
\hline V2 & 147 & 0.10 & 0.973 & 130 & 12.98 & 1.12 & 0.994 & 140 & 0.20 & 1.84 & -7.21 & 0.999 & 129 \\
\hline V3 & 147 & 0.10 & 0.990 & 141 & 11.62 & 0.18 & 0.990 & 168 & 0.13 & 1.01 & -20.85 & 0.999 & 131 \\
\hline V4 & 232 & 0.09 & 0.897 & 267 & 28.34 & 4.68 & 0.997 & 262 & 0.28 & 9.76 & 4.93 & 0.998 & 228 \\
\hline V5 & 151 & 0.08 & 0.921 & 140 & 12.52 & 1.23 & 0.994 & 148 & 0.18 & 1.90 & -4.45 & 0.998 & 129 \\
\hline V6 & 135 & 0.09 & 0.895 & 101 & 8.35 & 0.43 & 0.990 & 118 & 0.13 & 1.14 & -15.25 & 0.999 & 118 \\
\hline V7 & 115 & 0.06 & 0.966 & 80 & 5.79 & 1.37 & 0.997 & 82 & 0.15 & 2.05 & 0.32 & 0.998 & 82 \\
\hline V8 & 219 & 0.12 & 0.821 & 179 & 21.05 & 1.25 & 0.993 & 189 & 0.25 & 2.18 & -9.54 & 0.997 & 200 \\
\hline V9 & 272 & 0.12 & 0.810 & 277 & 33.67 & 1.38 & 0.999 & 273 & 0.29 & 3.08 & 5.58 & 0.999 & 247 \\
\hline V10 & 261 & 0.11 & 0.835 & 263 & 31.95 & 1.62 & 0.998 & 249 & 0.32 & 4.30 & 15.44 & 0.998 & 233 \\
\hline V11 & 277 & 0.11 & 0.857 & 265 & 29.88 & 1.54 & 0.999 & 263 & 0.27 & 3.09 & 4.53 & 0.999 & 244 \\
\hline V12 & 174 & 0.10 & 0.856 & 139 & 13.09 & 0.65 & 0.987 & 166 & 0.15 & 1.15 & -26.42 & 0.997 & 158 \\
\hline V13 & 234 & 0.07 & 0.936 & 175 & 15.92 & 1.60 & 0.994 & 187 & 0.18 & 2.11 & -8.07 & 0.998 & 189 \\
\hline V14 & 274 & 0.13 & 0.794 & 278 & 39.16 & 1.84 & 0.999 & 266 & 0.37 & 5.25 & 14.32 & 0.998 & 250 \\
\hline V15 & 179 & 0.11 & 0.841 & 147 & 14.32 & 0.54 & 0.985 & 175 & 0.16 & 1.13 & -27.59 & 0.995 & 164 \\
\hline V16 & 224 & 0.10 & 0.870 & 215 & 21.51 & 1.05 & 0.994 & 225 & 0.20 & 1.88 & -8.23 & 0.998 & 199 \\
\hline V17 & 154 & 0.08 & 0.916 & 116 & 10.53 & 1.20 & 0.990 & 130 & 0.17 & 1.59 & -12.24 & 0.997 & 131 \\
\hline V18 & 191 & 0.10 & 0.860 & 170 & 16.89 & 0.90 & 0.992 & 187 & 0.19 & 1.57 & -14.20 & 0.998 & 171 \\
\hline V19 & 201 & 0.12 & 0.823 & 189 & 21.11 & 1.10 & 0.998 & 191 & 0.25 & 2.39 & 0.57 & 1.000 & 183 \\
\hline V20 & 214 & 0.09 & 0.889 & 174 & 19.04 & 1.75 & 0.998 & 176 & 0.25 & 3.04 & 0.06 & 0.999 & 184 \\
\hline
\end{tabular}

chosen to show the difference among the three kinetic models, and the results are shown in Figs. 2, 3, 4. The parameters were all determined using non-linear regression through OriginPro 8.0 (OriginLab, USA) except $t$. Generally, $\mathrm{R}^{2}$ of the first-order kinetic model ranged from 0.794 to 0.990 which were lower than that obtained from the Gompertz kinetic model (0.985-0.999) and the MBPPSA kinetic model $(0.995-1.000)$. The $\mathrm{R}^{2}$ values of three kinetic models indicated that the modified Gompertz model and MBPPSA model were more suitable for the $\mathrm{AD}$ of leafy vegetable residues than the first-order model. By comparing $B_{0}$ (simulated maximum cumulative methane yield) and EMY, the $B_{0}$ value of each type of vegetable was found to be relatively close to the EMY value in both the modified Gompertz and the MBPPSA model.

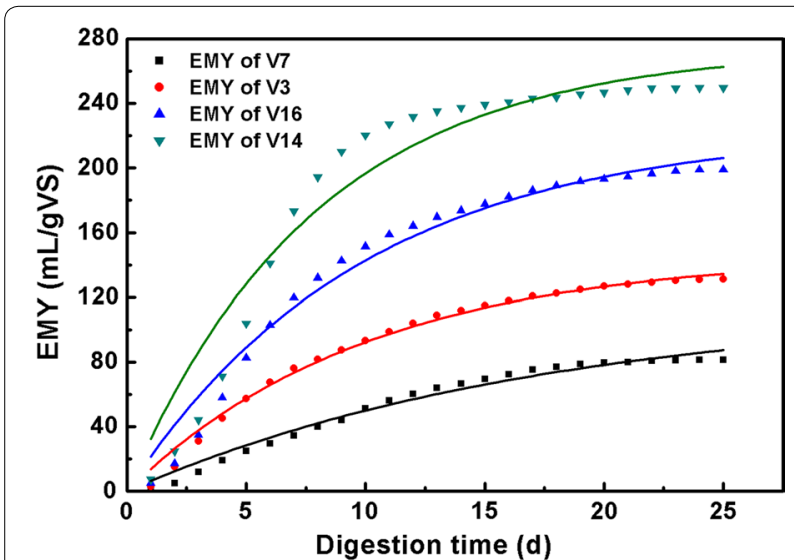

Fig. 2 Results of nonlinear curve fitting of four representative leafy vegetables in first-order kinetic model

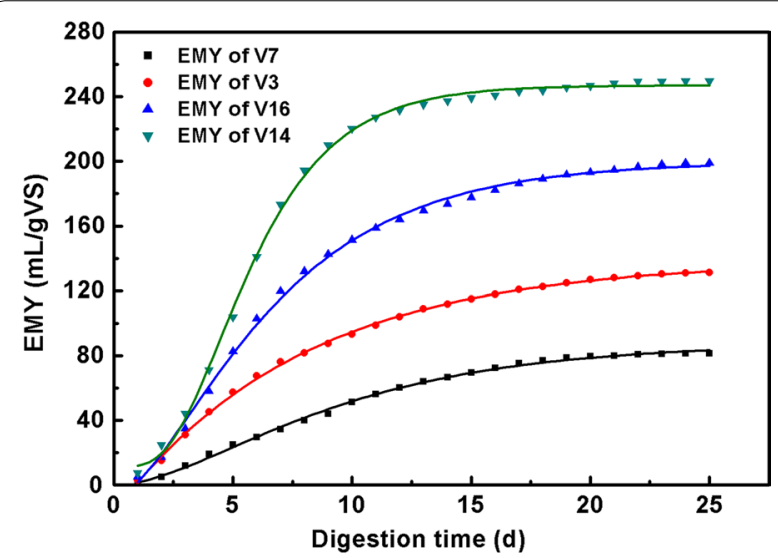

Fig. 3 Results of nonlinear curve fitting of four representative leafy vegetables in modified Gompertz model 


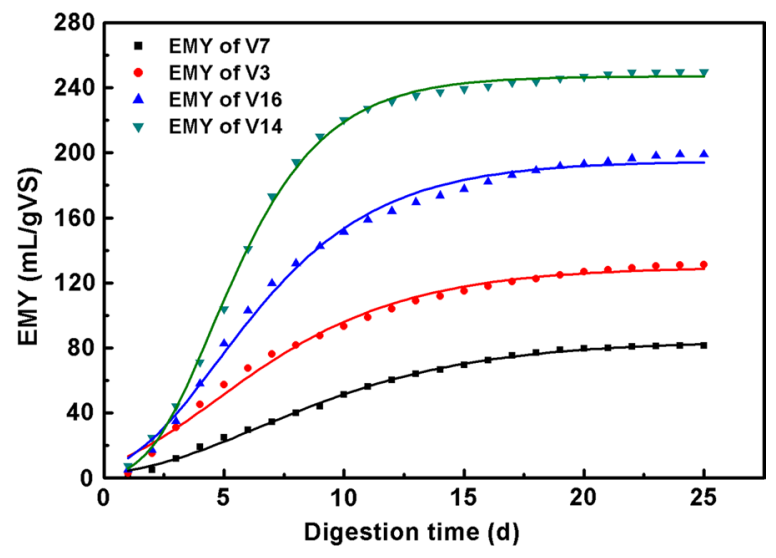

Fig. 4 Results of nonlinear curve fitting of four representative leafy vegetables in MBPPSA model

\section{Discussion}

Generally, results from Tables 2 and 3 indicated that vegetables with high hemicellulose contents (over 55\%) produced higher methane yields (over $200 \mathrm{~mL} \mathrm{~g}_{\mathrm{VS}}^{-1}$ ), with the exception of Chinese cabbage. Compared with other vegetables, schizonepeta showed poor potential for methane production, maybe because it had the lowest hemicellulose content and relative low VS/TS ratio among the vegetables. Poor methane yield has been also found for common andrographis, spinach, and amaranth wood, it might be owning to the low VS/TS. As well known, lignin content is another factor to influence the AD performance ( $\mathrm{Li}$ et al. 2013b). It could be found that vegetable residues with a lignin content higher than 10\% (V3, V5, V7, V17, V18), all possessed relatively low EMY. Collectively, the VS/TS ratio, lignin content, and hemicellulose content were important but not the only factors determining methane yield in anaerobic digestion.

In general, the BD and EMY values collectively determine whether a single substrate is suitable for $\mathrm{AD}$ to a certain extent. Through the analysis of the data in Table 4, substrates with higher EMY and BD were considered to have a good performance during AD tests. In addition, for the substrates with a low BD, certain pretreatment methods might make them more easily to be digested through the way of destroying the compact structure which is worthwhile to be researched in future.

It could also be found from Table 4 that the values of EMY' and EMY were relatively close except for V6 (an outlier). A reliable connection between biochemical components and biogas performance has thus been established. The EMY values of leafy vegetables could be predicted well using this equation, which were considered to be more valuable and practical than the MMP. The results represented a worthwhile reference for examining the digestion of mixed leafy vegetables in further study.
In the modified Gompertz model, cauliflower showed the highest $\mu$ (maximum methane production rate) of $39.16 \mathrm{~mL} \mathrm{~g}_{\mathrm{VS}}^{-1} \mathrm{~d}^{-1}$, and schizonepeta showed the lowest $\mu$ of $5.79 \mathrm{~mL} \mathrm{~g} \mathrm{gS}^{-1} \mathrm{~d}^{-1}$. A low value of $\mu$ corresponds to a low biogas production rate, which will eventually lead to poor biogas production. The $\lambda$ (lag phase) values were all below 2 days except for the young garlic shoots (4.68 days), and a short lag time is preferred for AD. In the MBPPSA model, vegetables with higher $k$ values (the constant of the model) showed better potential in methane production. The $I_{0}$ values (the inhibition/stability/feasibility determination factor) ranged from -27.59 to 15.44 . A negative value of $I_{0}$ implied that the AD process was stable, while a positive $I_{0}$ value indicated inhibition or instability. Normally, the higher the absolute negative and positive values of the $I_{0}$ is, the more stable or instable the digester will be, respectively, however, it can not be concluded that good stability will result in high methane production.

In conclusion, after measuring the characteristics of 20 types of leafy vegetable residues and exploring their methane production potential with a simple and unified method, a dependent relationship was established between the EMY and the organic components to predict the AD performance. Results also showed that the VS/TS ratio, lignin content, and hemicellulose content exerted a combined influence on the methane yield. In addition, three kinetic models were used to evaluate the $\mathrm{AD}$ process of these agro-wastes. This research will not only serve as a reference for further study on the biogas production from different substrates but also contribute useful information for agro-industrial applications of vegetable wastes in the future.

\section{Abbreviations}

AD: anaerobic digestion; BD: biodegradability; TS: total solid; VS: volatile solid; MMP: theoretical maximum methane production; EMY: experimental methane yield.

\section{Authors' contributions}

HY performed the experiments, created the graphs and drafted this manuscript. CC and GQL conceived of the study, designed the experiments and helped to draft the manuscript. RHZ participated in the design of the study. CZ, CYX and JFZ performed the modeling analysis. All authors read and approved the final manuscript.

\section{Author details}

${ }^{1}$ Biomass Energy and Environmental Engineering Research Center, College of Chemical Engineering, Beijing University of Chemical Technology, 505 Zonghe Building, 15 North 3rd Ring East Road, Beijing 100029, China. ${ }^{2}$ College of Life Science and Technology, Beijing University of Chemical Technology, Beijing 100029, China. ${ }^{3}$ Department of Biological and Agricultural Engineering, University of California, Davis, CA 95616, USA.

\section{Competing interests}

The authors declare that they have no competing interests.

Availability of data and materials

All data are fully available without restriction. 


\section{Consent for publication}

This manuscript does not contain any individual person's data.

\section{Ethics approval and consent to participate}

No animal or human subjects were used in this work.

\section{Funding}

This study was funded by the National Key Technology Support Program of China (2012BAC25B06, 2012BAC25B05) and the Fundamental Research Funds for the Central Universities (YS1407).

Received: 22 November 2016 Accepted: 4 January 2017

Published online: 25 January 2017

\section{References}

Appels L, Lauwers J, Degrève J, Helsen L, Lievens B, Willems K, Van Impe $J$, Dewil R (2011) Anaerobic digestion in global bio-energy production: potential and research challenges. Renew Sust Energ Rev 15(9):4295-4301

Clesceri LS, Eaton Andrew D, Greenberg Arnold E, Association American Public Health (eds) (2012) Standard methods for the examination of water and wastewater. American Public Health Association, Washington, DC

Barbosa H, Slater NKH, Marcos JC (2009) Protein quantification in the presence of poly(ethylene glycol) and dextran using the Bradford method. Anal Biochem 395(1):108-110

Buswell AM, Mueller HF (1952) Mechanism of methane fermentation. Ind Eng Chem 44(3):550-552

Di Maria F, Sordi A, Cirulli G, Gigliotti G, Massaccesi L, Cucina M (2014) Cotreatment of fruit and vegetable waste in sludge digesters. An analysis of the relationship among bio-methane generation, process stability and digestate phytotoxicity. Waste Manag 34(9):1603-1608

Li Y, Feng L, Zhang R, He Y, Liu X, Xiao X, Ma X, Chen C, Liu G (2013a) Influence of inoculum source and pre-incubation on bio-methane potential of chicken manure and corn stover. Appl Biochem Biotechnol 171(1):117-127

Li Y, Zhang R, Liu G, Chen C, He Y, Liu X (2013b) Comparison of methane production potential, biodegradability, and kinetics of different organic substrates. Bioresour Technol 149(12):565-569

Li Y, Zhang R, Liu X, Chang C, Xiao X, Lu F, He Y, Liu G (2013c) Evaluating methane production from anaerobic mono- and co-digestion of kitchen waste, corn stover, and chicken manure. Energy Fuels 27(4):2085-2091

Liu X, Zicari SM, Liu G, Li Y, Zhang R (2015) Pretreatment of wheat straw with potassium hydroxide for increasing enzymatic and microbial degradability. Bioresour Technol 185:150-157

Lo HM, Kurniawan TA, Sillanpää MET, Pai TY, Chiang CF, Chao KP, Liu MH, Chuang SH, Banks CJ, Wang SC (2010) Modeling biogas production from organic fraction of MSW co-digested with MSWI ashes in anaerobic bioreactors. Bioresour Technol 101(16):6329-6335
Marsden WL, Gray PP, Nippard GJ, Quinlan MR (2007) Evaluation Of The Dns Method For Analysing Lignocellulosic Hydrolysates. J Chem Technol Biot 32(7-12):1016-1022

Miller GL (1959) Use of dinitrosalicylic acid reagent for determination of reducing sugar. Anal Chem 31(3):426-428

Molino A, Nanna F, Ding Y, Bikson B, Braccio G (2013) Biomethane production by anaerobic digestion of organic waste. Fuel 103:1003-1009

Molinuevo-Salces B, García-González MC, González-Fernández C, Cuetos MJ, Morán A, Gómez X (2010) Anaerobic co-digestion of livestock wastes with vegetable processing wastes: a statistical analysis. Bioresour Technol 101(24):9479-9485

Owamah HI, Izinyon OC (2015) Development of simple-to-apply biogas kinetic models for the co-digestion of food waste and maize husk. Bioresour Technol 194:83-90

Rincon B, Heaven S, Banks CJ, Zhang Y (2012) Anaerobic digestion of wholecrop winter wheat silage for renewable energy production. Energy Fuels 26(4):2357-2364

Rincón B, Heaven S, Banks CJ, Zhang Y (2012) Anaerobic digestion of wholecrop winter wheat silage for renewable energy production. Energy Fuels 26(4):2357-2364

Scano EA, Asquer C, Pistis A, Ortu L, Demontis V, Cocco D (2014) Biogas from anaerobic digestion of fruit and vegetable wastes: experimental results on pilot-scale and preliminary performance evaluation of a full-scale power plant. Energy Convers Manag 77:22-30

Silvério SC, Sérgio M, Milagres AMF, Macedo EA, Teixeira JA, Mussatto SI (2012) Interference of some aqueous two-phase system phase-forming components in protein determination by the Bradford method. Anal Biochem 421(2):719-724

Syaichurrozi I, Budiyono, Sumardiono S (2013) Predicting kinetic model of biogas production and biodegradability organic materials: biogas production from vinasse at variation of COD/N ratio. Bioresour Technol 149(4):390-397

Van Soest PJ, Robertson JB, Lewis BA (1991) Methods for dietary fiber, neutral detergent fiber, and nonstarch polysaccharides in relation to animal nutrition. Dairy Sci 74(10):3583-3597

Xu F, Li Y (2012) Solid-state co-digestion of expired dog food and corn stover for methane production. Bioresour Technol 118:219-226

Yao Y, Luo Y, Yang Y, Sheng H, Li X, Li T, Song Y, Zhang H, Chen S, He W, He M, Ren Y, Gao J, Wei Y, An L (2014) Water free anaerobic co-digestion of vegetable processing waste with cattle slurry for methane production at high total solid content. Energy 74(2):309-313

Zhu J, Zheng Y, Xu F, Li Y (2014) Solid-state anaerobic co-digestion of hay and soybean processing waste for biogas production. Bioresour Technol 154(2):240-247

\section{Submit your manuscript to a SpringerOpen ${ }^{\odot}$ journal and benefit from:}

- Convenient online submission

- Rigorous peer review

- Immediate publication on acceptance

- Open access: articles freely available online

High visibility within the field

- Retaining the copyright to your article

Submit your next manuscript at springeropen.com 